\author{
Ružica Rašperić \\ Zagreb County Tourist Board, Vern' University of Applied Sciences, Zagreb, Croatia \\ Romana Lekić \\ Vern' University of Applied Sciences, Tourism Department, Zagreb, Croatia \\ Lidija Fištrek \\ Vern' University of Applied Sciences, Zagreb, Croatia \\ UDC 338.48-6:7/8(497.5) \\ $378.147: 338.48$
}

\title{
RELATION BETWEEN CREATIVE TEACHING AND SUSTAINABLE PRACTICES IN CULTURAL HERITAGE TOURISM
}

\begin{abstract}
This paper is primarily concerned with alternative teaching methodologies. Creative teaching methodologies place the student at the center of the learning process. This paper is a case study of "Orion - promotion of the Vučedol culture" project as a self-sustainable cultural product. The primary goal of the project is the promotion of heritage through cultural tourism. The "Orion" project was launched in cooperation with third year undergraduate students at the Department of Tourism of VERN University of Applied Sciences from Zagreb, as part of the Event Management and Marketing course (March to June 2014). Inspired by the Vučedol archaeological site, historical data and lectures on the Vučedol culture and the oldest Indo-Eu-
\end{abstract}

\section{Introduction}

Tourism and Hospitality programs are extremely diverse in nature; some focus specifically on the development of practical skills, while others specialize in developing generic management capabilities. Some of academic institutes offer programs combining practical and theoretical elements. Discontent among industry leaders with the quality of undergraduate students emerging from tourism and hospitality management programs has provided the catalyst for much of this reform. ropean calendar called "Orion," the students have developed a plan for a two-day festival that would take place in Vinkovci, Croatia and would include a scientific conference, cultural and artistic program, presentation of local cuisine, creative workshops, and promotion of local crafts.

This paper reinforces the need for imaginative thinking in education for tourism. The variety of ways in which creative teaching practices can be used is infinite and this case study presents only a small contribution.

Key words: creative teaching, alternative teaching methodologies, Vučedol culture, imaginative thinking, cultural heritage tourism

Education is fundamentally concerned with improving the cognitive abilities of learners (Fullan 2003). Therefore, highereducation providers are constantly searching for the most effective means of developing students' holistic awareness (Jackson 2006) and creativity is central to this process. There is little doubt that teaching methods have evolved in recent years. Creative teaching is not a new concept and there are numerous teaching aids available to develop competencies relating to creative teaching (Williams 1992).

This paper is primarily concerned with alternative teaching methodologies which 
are removed from the traditional demonstration style of lecturing frequently associated with higher education. Creative teaching methodologies place the student at the center of the learning process. Creativity in teaching is frequently an unconscious act (Jackson 2002). Fostering creativity within higher education is a primary goal of both the European University Association (2007) and the Higher Education Authority (2011). It is the process for supporting individuals in their personal and later professional growth so they can fulfil their potential by becoming all they can become and thereby find personal fulfilment. The focus of creative development should always be on helping students to become authentic and fully selfactualized. This means supporting the individual in his or her own evolution as well as supporting the evolution of consciousness of humanity.

\section{Teaching creatively}

According to Jayawardena (2001), contemporary tourism and hospitality-management education requires the re-evaluation of teaching strategies. In addition, curricula should be developed to enhance communication, analytical skills, creativity and the ability to synthesize information. Ashley et al., (1995) illustrated this concept with clarity when they presented findings from a group discussion involving twenty-five leading hospitality executives. The group identified ten categories of specific technical skills required by tourism and hospitality-management graduates:1) People skills; 2) creative thinking ability; 3) financial skills; 4) communication skills (for both written and oral presentations); 5) developing a service orientation; 6) total quality management; 7) problem-identification and problem-solving skills; 9) customer feedback skills and 10) individual and system-wide computer skills (Ashley et al., 1995, p. 77).

Notable creative teaching methodologies indicated by academics and students included: case studies; group work; discussions; problem-based learning (PBL), role play, demonstrations (practical classes); YouTube; Internet; videos and PowerPoint. Some hospitality academics were adopting very creative teaching techniques such as Twitter and game-based learning very successfully. Other techniques mentioned were a grammar auction, article reviews, story boarding and word searches.

This study also revealed that both students and academics perceive a need for creative teaching methodologies. These results support Jackson's (2006, p.2) statement that "Higher education needs to see creativity within the important role it plays in preparing people for an uncertain and even more complex world of work".

The Conceptual Model ${ }^{1}$ for creative development: Creative Teacher + Creative Classroom + Students develops creative capabilities $=$ Graduate demonstrates creative capabilities in the workplace

\section{Step 1: The Creative Teacher}

The literature review have led the author to conclude that following elements must be present if a teacher wishes to engage in the development and execution of creative teaching methodologies. The following section explores each element in further detail:

Based on McGoldrick, C. (2000) and McWilliams,E. (2008) with research undertaken by Tait (2002) and Malone and Gardner (2011) 


\begin{tabular}{|l|l|}
\hline Risk taker & $\begin{array}{l}\text { Must be willing to take risks, you have to reveal your weakness and } \\
\text { relinquish control of the learning situation. }\end{array}$ \\
\hline Teaching qualification & $\begin{array}{l}\text { Provides an understanding of different learning styles, provision of } \\
\text { appropriate structures and tools conducive to learning. }\end{array}$ \\
\hline $\begin{array}{l}\text { Imagination, Innova- } \\
\text { tion }\end{array}$ & $\begin{array}{l}\text { Innovation, inventing, task conceptualization, problem solving and } \\
\text { development of creative challenges. }\end{array}$ \\
\hline Resources & $\begin{array}{l}\text { Fully utilizing all the teaching tools and resources available. Thinking } \\
\text { outside the box i.e. if space is an issue, tries and relocate some or part } \\
\text { of the class. }\end{array}$ \\
\hline Physical space & Allow students space to generate their own ideas. \\
\hline Commitment & Creativity takes time and effort and does not always work. \\
\hline Facilitative & $\begin{array}{l}\text { Acting as a guide in the learning process. Observing tasks evolve and } \\
\text { develop. Motivating students to become independent thinkers. }\end{array}$ \\
\hline Supportive & $\begin{array}{l}\text { Encouraging students to engage, become risk takers. Students value } \\
\text { being rewarded for their creativity. Teachers must nurture the crea- } \\
\text { tive process. }\end{array}$ \\
\hline Emotionally Intelligent & $\begin{array}{l}\text { Teachers must be aware of the mood of the class. Atmosphere and } \\
\text { student disputation can arise during an exercise. By using emotional- } \\
\text { intelligence skills teachers can help prevent difficulties from arising } \\
\text { in the class. }\end{array}$ \\
\hline
\end{tabular}

\section{Step 2: The Creative Classroom}

This paper has concluded that the traditional practice of teachers transferring knowledge to learners without active student engagement is inadequate in the development of creative capacity building. Therefore, the creation of a learning environment that nurtures creativity is vital. The creative classrooms encourage learners to take ownership of their individual learning, by using a facilitative, collaborative approach. The conditions identified are designed to promote student creativity, encourage creative practices, the development of transferable skills, encourage flare and build confidence. This list is by no mean exhaustive:

\begin{tabular}{|l|l|}
\hline IT Resources & $\begin{array}{l}\text { The availability of IT resources can enhance the learning envi- } \\
\text { ronment with sound, images and access to unlimited knowledge. }\end{array}$ \\
\hline Environment & $\begin{array}{l}\text { Teacher acts as a facilitator where there are no right and wrong } \\
\text { answers, just possibilities. }\end{array}$ \\
\hline Trust & $\begin{array}{l}\text { The development of a unique relationship between teachers and } \\
\text { learners. In addition, this gives learners the confidence to expe- } \\
\text { riment. }\end{array}$ \\
\hline Participation & $\begin{array}{l}\text { Learners will only fully commit to the process after observing tea- } \\
\text { chers practicing and demonstrating creativity. }\end{array}$ \\
\hline Cooperation & $\begin{array}{l}\text { Learner takes greater responsibility for their learning. Teachers re- } \\
\text { frain from critical feedback. }\end{array}$ \\
\hline Space & $\begin{array}{l}\text { To think, experiment, move. Also refers to a personal space where } \\
\text { ideas are nurtured and allowed to grow. }\end{array}$ \\
\hline
\end{tabular}




\begin{tabular}{|l|l|}
\hline $\begin{array}{l}\text { Innovative approaches to } \\
\text { teaching }\end{array}$ & $\begin{array}{l}\text { Tasks are based on real-world situations. Activities must be mea- } \\
\text { ningful. }\end{array}$ \\
\hline $\begin{array}{l}\text { Innovative approaches to } \\
\text { assessment }\end{array}$ & $\begin{array}{l}\text { Assessment must be multifaceted. As learners are co-constructing } \\
\text { their learning, the use of peer and self-assessment is appropriate. }\end{array}$ \\
\hline Reflection & Reflective practices are encouraged in a variety of forms. \\
\hline
\end{tabular}

\section{Step 3: The Creative Student and Graduate}

By adopting Steps One and Two, it is anticipated that the creative student will develop transferable skills in the following areas:

\begin{tabular}{|l|l|}
\hline Critical thinking & Making sense of complexity. \\
\hline Creativity & Increased awareness of personal creativity. \\
\hline Team work capabilities & $\begin{array}{l}\text { Learns to work as part of a team, time management, task allocation, } \\
\text { negotiation skills are all developed. }\end{array}$ \\
\hline Interpersonal skills & People and organizational skills. \\
\hline Logical & Thinking non-linearly, system thinking \\
\hline Independent learner & Increased sense of responsibility for own learning \\
\hline Reflective & $\begin{array}{l}\text { Reflects on practices and processes, to identify and amend shortco- } \\
\text { mings. This process can involve peer critique. }\end{array}$ \\
\hline Confident & In own voice, capabilities. \\
\hline Adaptable & Open to possibilities. \\
\hline Ownership & Takes responsibility for own learning. \\
\hline Commitment & $\begin{array}{l}\text { Completing tasks and lifelong commitment to professional develo- } \\
\text { pment }\end{array}$ \\
\hline
\end{tabular}

\section{From a creative student all the way to creative cultural tourism}

A case Study: a Project by Third-Year Students of Tourism of the VERN University of Applied Arts in Zagreb

Richards (2011, p.123) defined creative cultural tourism as "tourism which offers visitors the opportunity to develop their creative potential through active participation in courses and learning experiences which are characteristic of the holiday destination where they are undertaken."
The definition carries several significant implications:

- Creative potential - the tourist is equipped with tools for developing their own creative potential, enabling them to take home something more than souvenirs. This ability represents learning and creation experience that can affect the change of the tourist's worldview.

- Active participation - the consumer is actively involved in the creative process, and this involvement creates potential for true connection and engagement with local population and local culture. 
- Specific experiences - creativity can happen anywhere, but the important thing is to link the creative process to the destination and to anchor it in local culture, creativity and identity. This process requires not only creativity on the part of the tourist, but also the destination.

- Co-creation or co-maker ship - the concept of creative tourism involves, to some extent, a level of co-creation between visitors and locals.In its simplest implementation, this concept involves using the consumers' knowledge of the product to improve the product and make it fit better into the needs of consumers.

UNESCO (2006, p.3) states that "creative tourism is travel directed toward an engaged and authentic experience, with participative learning in the arts, heritage, or special character of a place, and it provides a connection withthose who reside in this place and create this living culture."

There are several other definitions of creative tourism, but what all definitions have in common are interactive, participative and authentic experiences that enable tourists to develop their creative potentials and skills in contact with the local population. This means that creative tourists are a group of active participants without whose active participations there would be any creative experiences. The creation of creative tourism experiences should include all four dimensions of experience economy: education, escapism, esthetics, and entertainment (Pine and Gilmore, 1999).

On the track of the concept and definition of creative cultural tourism, and towards the four cited implications, the curriculum of the Event Management and Marketing course was complemented by a creative project that enabled the students to participate actively and demonstrate their creative potential through team co-creation, inspired by the phenomenon of Vučedol culture through specific experiences. This enabled them to be involved in an authentic experience, with participative learning about the heritage and special characteristics of places visited by them in their field course.

\section{Acting and thinking in terms of project management}

A case Study: a Project by Third-Year Students of Tourism of the VERN University of Applied Arts in Zagreb

Thinking in terms of project management involves accumulating efforts and skills for solving a particular problem. In cases where educators and moderators are in a position to motivate and inspire, a real interest in the subject of investigation is obligatory. It means that the emotional component should be taken into account. How to make unique, creative and innovative tourist products in a tourist destination should be inspired by future activity, they should have a variety of ideas and anticipations for the future, they should be planning out an occupation for future. This type of activity allows the focus to switch to the subject of investigation and onto collaborative work.

All participants are in touch. They are open to change because they seek out new ideas. They readily accept new ideas, experiences, opportunities and ways of doing things. They integrate the changes into an ongoing process. The activity of a moderator and educator is focused on the results. That is to focus attention on the most important priorities and stand up for what is right, what is better, what is appropriate and what benefits the project. The collective wisdom of the group and group activities double the excitement and joy all the while sharing ideas. The moderator and educator keep the discussion within the subject and realistic, although a degree of imagination is appreciated.

The peculiarity of this kind of work is personal responsibility for what you are do- 
ing and a shared responsibility for the result. It helps to learn from successes and failure and to encourage one another. Such kind of activity assumes a systemic approach to improving the process across disciplines. The participants, together with the moderator and the educator, build collaborative relationships. Thinking in terms of project management is based on the relation between memory and emotions caused by the particular life experience.Each information processing situation is assumed to result in activation of memory traces and a construction of new memory traces (Padovan and Versace 1998).

An emotional response to a picture is revealed when it is associated with acquired emotional experiences or if evokes interest because it is not associated with existing emotional experiences. Students show surprise when they notice violations of expected events or as a response to discovery. Surprise can reflect both a violation as well as a confirmation of expectancy. Excitement, creativity, and brainstorming all evoke strong emotional response on the part of the adults. It leads to semantic trace. It results in activation of memory traces. Repeated experience of the kind benefits creativity and is strongly associated with something inspiring and pleasant with a positive emotional feedback.

Insufficient knowledge of the Vučedol culture and findings, which remain as fascinating in the $21^{\text {st }}$ century as before, have incited the need for designing a project as a self-sufficient product that would primarily promote historical heritage through cultural tourism. The Orion Festival project as a self-sufficient product inspired by the cultural heritage of Croatia was created as part of the Event Management and Marketing course, by third-year students of tourism of the Vern University of Applied Arts in Zagreb. The aim of this course is to familiarize students with the country's tangible and intangible cultural heritage of attractive tour- ist destinations, so that students, inspired by the rich Croatian heritage, could design a cultural tourism product and the promotion of such product. The effort to link tradition and modernity as a cultural tourism product that would prove attractive to the general population in contemporary times served as the driving force behind this project assignment.

By promoting the Vučedol culture, the "Orion" project would bring the general public closer to recently discovered information on the Vučedol culture, educate on historical and archeological facts on the culture, inspire individuals to do creative work, promote cooperation with institutions and creative industries, secure a recognizable tourist destination, brand the ORION product, promote it domestically and abroad and forge cooperation with countries within the same region as Croatia. Inspired by their field course and visit to the archeological site of Vučedol, historical information and lectures on the Vučedol culture and Orion - the oldest Indo-European calendar - the students designed a festival project of primarily self-sufficient character. Since the students are majoring in tourism, emphasis was placed on educational and cultural aspects, tourism offers and promotion of cultural heritage.Regular students, part-time students and Erasmus foreign exchange students all participated in the project.The students were divided into teams: organization and logistics team, team tasked with the scientific part of the festival program, team tasked with the cultural and artistic festival program, hospitality offer team, team tasked with creating visual promo material and media relations team.

The Vučedol cultural festival was named "Orion" after the first Indo-European calendar, dating back to 3000 BC. Since the festival is predetermined thematically, the students designed a two-day outdoor festival programme offer. As the festival location, the students chose the central square of 
Vinkovci, consisting of a promenade and a park just in front of the Vinkovci City Museum, the collection of which includes both the Orion calendar itself and other important artefacts from the Eneolithic period. A mosaic depicting the Orion constellation is the special attraction of said promenade and plaza in Vinkovci. As a picturesque destination that is attractive from a tourist point of view, it encouraged the students to place the performance-related part of the festival on the visually authentic location of the city promenade.

The festival programme was envisioned as a multi-level programme consisting of an educational part with plenary discussions of internationally recognized archeology and anthropology experts and of a series of lectures on the Vučedol culture. The students designed a fashion show inspired by reconstructing Eneolithic clothing and a programme inspired by shamanic customs of ancient inhabitants of Vučedol (according to the archeologist Durman, the famous copper vessel known as the Vučedol dove (partridge) was cast by a shaman, who used it to drink hallucinogenic drugs that altered his consciousness, enabled him to cross over to other worlds and connect with souls of the departed). Aside from the dance workshop and shamanic rituals workshop, a special part of the programme was dedicated to tattoo and body painting (the students were inspired by studying the tattooing methods of female Vučedol inhabitants). Another part of the educational and entertainment festival offer workshops for making copper pottery and tools in accordance with historical records. The entertainment programme would include the performance of the national folk dance ensemble LADO, a tournament to determine the most creatively designed menu inspired by authentic food of Vučedol inhabitants and a full evening's DJ program.

The self-sufficiency of the "Orion" festival as a product promoting cultural herit- age would include the following incomes: income from leases of festival exhibitors, admission tickets, festival hospitality offer and sale of original souvenirs inspired by the Vučedol culture. In terms of its offer, the "Orion" festival, as a tourist attraction, would draw the attention of the media, as well as many sponsors and donors.

Promoting cultural tourism using a festival as an event depicting the customs and way of life of the Vučedol culture coupled with modern, $21^{\text {st }}$ century way of life is a very innovative concept and presents an attractive combination of traditional and modern elements. The students were given the opportunity to realize the identity that marks the uniqueness of our heritage. Driven by their creativity and the opportunity to transform their talents and passion into a tourism product - a festival - they realized that what tourists are looking for is the kind of authentic experience outside of their usual, everyday life that would enable them to become part of new communities in their search for local cultures. While being connected with Erasmus foreign exchange students and their older part-time colleagues, the regular students felt the need to belong, which fueled their desire for group integration. Although it was to be expected that older students would be the bearers of creativity in this project, regular students showed surprising maturity, even though they were still inexperienced and "playful". A sense of belonging is an important aspect of tourism experience, with the sense of belonging to a group encouraging social learning and participating in interactions. The scope of existing resources encompassed by the Vučedol culture phenomenon is very broad and can have different characteristics, ranging from tangible to intangible, from natural to cultural. Thus, the students learned that heritage-related resources could take different forms, such as landscapes, buildings, knowledge and skills. By using the Orion festival to present heritage, they utilized different stories inspired by 
the way of life and spirit of ancient Vučedol inhabitants, i.e. the mechanisms of storytelling and the "Scheherazade strategy" (Simon 2011; based on Lekić 2013), including:

- Presenting heritage through a story that needs to be constructed using the narrative identity of the location (storyline);

- Placing the story during the time of the festival, controlling the rhythm and narrative tension during the festival (timing);

- Framing the message of the festival, i.e. emphasizing top attractions and stories as primary tourist appeal;

- Creating an online and field network, i.e. a hybrid environment used to draw attention and structure a desirable market niche (networking).

\section{Conclusion}

Cultural resources are the leading product of a tourist destination and should be advertised as such. What makes one tourist destination different is its cultural heritage. Culture is the prime element of tourist attraction and brand-creation in tourist management today. This paper has suggested the inclusion of creative development in the curricula of tourism and hospitality students. Planning requires active participation and inclusion in shaping tomorrow and empowerment is what these students need in order to make their voices heard. Entirely independently from the economic importance of creative industries, creativity centered on art and culture is recognized today as a tool which can create a creative experience which can influence human behavior. Independently from its esthetic values, creativity based on culture also includes the implementation of different points of view and values, while creating and emotional bond with a certain product.

The basis and background of empowerment can only be information, knowledge of the sustainability practices, so it is of imperative importance that university students are provided interdisciplinary creative courses because it is only with the help of transformative pedagogies that learners (and therefore classes and learning communities) can turn into inquisitive, reflective, experienced and critical thinking individuals - the basic unit of a sustainable society.

Creativity is one of the crucial drivers of modern economies. Modern economies are characterized by new forms of consumption and new forms of organization of economic activities. These new forms of consumption primarily include: speed which lessens the attractiveness of a certain product (especially in information technology), adaptation (individualization of a product according to the demands of a certain market) and intangible values (meanings, experiences, esthetics). It is precisely these characteristics which are closely connected to culture (esthetics, meanings, the ability to disrupt order, the ability to connect identities).

However, it is no longer sufficient to promote cultural heritage through traditional methods: using legends, famous individuals, historical events, literature, etc. to form multimedia presentations, guided tours, costumes, travel guides, etc. It is necessary to develop new cultural attractions, street shows with historical themes, music or film festivals, cultural events, traditional festivals, etc. The ultimate value or creative learning through project of Festival Orion lies in its opportunities for highly effective, competence-driven experiential learning. What students learn from their own understanding, observations and discussions makes a much deeper impression and has a longer lasting effect than any presentation of facts. This interactive approach also contributes to a better development of personal skills and coaching competences.

This paper reinforces the need for imaginative thinking in tertiary education. The variety of ways in which creative teach- 
ing practices can be used is infinite and this project only presents a small selection.

\section{References}

Ashley, R. A., Bach, S. A., Chesser, J. W., Ellis, E. T., Ford, R. C., LeBruto, S. M., Milman, A., Pizam, A., \& Quain, W. J., (1995) A customer based approach to Hospitality Education, Cornell Hotel and Restaurant Administration Quarterly, 36(4): 74-79

European University Association. (2007). Creativity in higher education, Brussels, Belgium: European University Association.

Fullan, M. (2003).Change Forces with a vengeance, London: Routledge Falmer Higher Education Authority (2011).National Strategy for Higher Education 2030: Report of the Strategy Group, Government publications, Dublin.

Jackson, N. (2006). Creativity in Higher education: Creating tipping point for cultural change, Surrey, Centre for Excellence in Professional Training and Education, University of Surrey, England.

Jackson, N.J. (2002). Designing for Creativity: A curriculum guide. Retrieved from: www. itsn.ac.uk/genericcentre

Jayawardena, C. (2001).Challenges in International Hospitality Management Education, International Journal of Contemporary Hospitality Management, 12(6): 310-315

Lekić, R. (2013). Hrvatska tradicijska baština $i$ kulturni turizam - Mogućnosti uključivanja Nematerijalne baštine preko reprezentativnih uzoraka [Croatian traditional heritage and cultural tourism - Opportunities of including intangible heritage using representa- tive samples], doctoral thesis, Faculty of Humanities and Social Sciences in Zagreb

Malone, J. and Gardner, J. (2011). The Creative Classroom, 29th EuroCHRIEConference, "Tourism and Hospitality, Drivers of Transition" October 19-22, Dubrovnik McGoldrick, C. (2002). Creativity and Curriculum Design: What Academics think, LTSN Generic Centre.

McWilliams, E. (2008). Unlearning how to teach, Innovations in Education and Teaching International, .45(3): 263-269.

Padovan C. \& R. Versace (1998); The Representation of Emotion in Long Term Memory; Apprentissage; des principles naturels aux method artificielles (ed. G. Ritschard, A. Berchtold, F.Duc, D.A. Zighed); Hermes (pp. 111-123)

Pine, B. J. \& Gilmore, J. H. (1999). The experience economy: work is theatre and every business is a stage. Boston Mass: HBS Press

Richards, G. (2011). Creativity and Tourism: The state of the Art. Annals of Tourism research, 38 (4), 1225-1253. Retrieved from: http://www.sciencedirect.com/science/article/pii/S0160738311001204 (18 December 2015)

Salmon, C. (2011), Strategija Šeherezade [The Scheherazade Strategy]. Belgrade: Multimedia Clio.

Salmon, K. (2010). Storytelling ili pričam ti priču. Belgrade, Multimedia Clio.

William, D. (1992) Some technical issues in assessment: a user's guide, British Journal of Curriculum an Assessment, 2(3): 11-21.

Tait, J. (2002) What conditions and environment could support teachers in finding space for "creativity" in their work with curriculum? York, LTSN Generic Centre. 